\title{
Preface ICAM 2009
}

\author{
Guillermo Solórzano
}

Received: 14 June 2010/ Accepted: 16 June 2010/Published online: 9 July 2010

(C) Springer Science+Business Media, LLC 2010

The papers included in this special issue were selected from more than 327 submitted manuscripts which themselves represent some of the best research presented at ICAM 2009. The International Conference on Advanced Materials (ICAM) is the most prestigious conferences of the International Union of Materials Research Societies (IUMRS) and is held in alternate years. The previous conferences in this series were held in Beijing, China (1999); Cancun, Mexico (2001); Yokohama, Japan (2003); Singapore (2005); and Bangalore (2007). The ICAM 2009 was organized together with the VIII Brazilian MRS Meeting-VIII Encontro SBPMat. This event was held in the beautiful city of Rio de Janeiro, Brazil, from 20 to 25 September 2009. Twenty-eight technical symposia, 8 plenary lectures, 2 workshops an Energy Forum and an exhibition composed the program. Each symposium featured invited talks, contributed oral and poster presentations.

About 1800 scientists from 47 countries gathered at the Windsor Convention Center at Barra da Tijuca, during this event. The program committee chaired by Elisa Bagio Saitovicth and Guillermo Solórzano assembled 28 symposia organized in seven major areas: Nanoscience and Nanotechnology, Health and Biological Materials, Energy and Environment, Structural Materials, Theory and Phenomena and General Interest each symposium was organized by selected group of International and Brazilian scientists with the support of an International scientific committee. The complete symposia topics and corresponding co-organizers are listed as follows: NANOSCIENCE AND NANOTECHNOLOGY A-Advances on

G. Solórzano $(\varangle)$

PUC-Rio de Janeiro, Rua Marquês de São Vicente 225,

Gávea, Rio de Janeiro 22451-900, Brazil

e-mail: guilsol@puc-rio.br
Nanocomposites: Synthesis and Applications by D.C. Bell, W. Jäger, and L.H.C. Mattoso; B-Mechanical Properties of Materials at the Nanometer Length Scales by A. Schwartzman, R. Prioli, J. Inoue, and J. Smith; C-Carbon Nanostructures: from properties to Applications A. Jorio, M. Terrones, and F.O. Plentz Filho, A. John Hart; DSynthesis, Characterization and Properties of Inorganic Nanoparticles by Paulo Ferreira, J. de Hosson, K. Sasaki, and D.A. Melo; E-Magnetic Materials at the Nanoscale by Maria-Elena Gómez, A. Hoffmann, E. Saitovitch, J.L. Vicent, and Y. Bruynseraede; F-Solving Nanostructures through Electron Microscopy by G. Van Tendeloo, G. Solórzano, U. Dahmen, and C. Bittencourt. HEALTH AND BIOLOGICAL MATERIALS G-Medical Applications of Nanotechnology by R. Sinclair, M. Welland, V. Dravid, and M. Farina; H-New Developments in Biomaterials by G. Gonzalez, R. Reichelt, C. Graeff, and Y. Missirlis; I-New Materials and Processes for Sensing and Biosensing by V. Zucolotto, S. Sanchez-Cortes, S. Manohar, and L.T. Kubota. ENERGY AND ENVIRONMENT J-Materials for Portable Energy Sources by P.R. Bueno, R.M. Torresi, B.V.R. Chowdari, C. Gabrielli, and J.M. Rosolen; KInnovation in Fuel Cells: from Materials to Novel Devices by E. Traversa, M. Linardi, R. Muccillo, E.D. Wachsman and E.R. Gonzalez; L-Environmentally Benign Materials by Fernando Galembeck, M.M. Rippel, K. Ghavami, and A. Dufresne; M-Frontiers in Photonic and Photovoltaic Materials and Processes by F.A. Ponce, H. Amano, E.R. Leite, M.C. Lux-Steiner, and A.F. Nogueira; N-Materials for Nuclear Power Generation by M.G. Burke, R. Versaci, A. Costa e Silva, R. Versaci, and Andre Costa e Silva; O-Materials for Direct Energy Conversion Systems by A. Sayir, T. Caillat, M.-H. Berger, C. G. Levi, and Hugo Sandim. FUNCTIONAL AND ELECTRONIC 
MATERIALS P-Designer Polymeric Nano and MicroStructures by E.L. Thomas, M. do Carmo Gonçalves, C. Ober, and Julius Vancso; Q-Materials and Processes for Large-Area Electronics by A. Salleo, Martin Heeney, Ana Claudia Arias, and Lucimara Stolz Roman; RProtective Coating: Advanced Surface Engineering by Fernando L. Freire Jr., Y.-W. Chung, and I.J.R. Baumvol; $\mathrm{S}-$ Current Trends in Oxide Materials by C.B. Carter, G. Padeletti, H.-J. Habermeier, and J.A. Eiras; T-Functional Materials for Organic Electronic and Nanotechnology by R.M. Faria, M. Cremona, G. Marletta, M. Mayor, and P. Samorì. STRUCTURAL MATERIALS U-Advances in Structural Ceramics-from Processing to Applications by Dachamir Hotza, C. P. Bergmann, R. Janssen, P. Colombo, and J. Labrincha; V-Structures and Properties of Metastable Materials by W.J. Botta Filho, D.S. dos Santos, A.R. Yavari, and R. Schulz; W-New Developments in the Processing and Applications of $\mathrm{Cu}$ ad Mo-Base Alloys by F. Lund, L. Amestica, E. Brocchi, H. Stillman, and N. Kinsman; X-Processing, Structure and Properties of Advanced Metallic Materials by $\mathrm{L}$. Godefroid, L.C. Rolim Lopes, C. Martins, Claudio Ruggieri, T.M.F. de Melo, and J.P. Ipiña. THEORY AND PHENOMENA Y-Computational Modeling and Data Driven Materials Discovery by K. Rajan, G. Gutierrez, P. Vashishta, H. Terrones Maldonado, and J.P. Rino; ZPhase Transformation in Metallic Systems: Current issues by H. Goldenstein, D. Farkas, J. Howe, and Y. Brechet. GENERAL INTEREST AA-Materials Education: Resources, Opportunities and Challenges by J.E.E. Baglin, M.G. Norton, and E.F. Lucas; BB-From Theory to Experiment: Advances in Engineering Materials by C.A. Taft, W.A. Lester, Jr., J.R. Sambrano, and V. Bouquet.

The program included 8 plenary sessions. Plenary 1: Subra Suresh (MIT School of Engineering, USA) "Nanotechnology and materials science perspectives to probe connections between human diseases and cell behavior"; plenary 2: Akihisa Inoue (President, Tohoku University, Japan): "Recent Development and Applications of Bulk Glassy Alloys"; plenary 3: Miguel Jose Yacaman (U Texas, USA): "New Insides on the Physics and Chemistry of Nanocristals"; plenary 4: C.N.R. Rao (Linus Pauling Professor \& JNCASR President, India): "Graphene: The new nanocarbon"; plenary 5: Professor Knut Urban (Forchungszentrum Julich, Germany): "Aberration-corrected electron microscopy-solving materials problems on the atomic level"; plenary 6: Jacques Amouroux (Université Pierre et Marie Curie, France): "Carbon dioxide: a New Material for Energy Storage”; plenary 7: Stuart S. P. Parkin (Director, IBM-Stanford SpinAps, USA): "The Spin on Electronics"; plenary 8: Henrique Toma (IQ-University of Sao Paulo, Brazil): "Supramolecular Hetero-Hybrid Materials and Devices" (Figs. 1, 2).

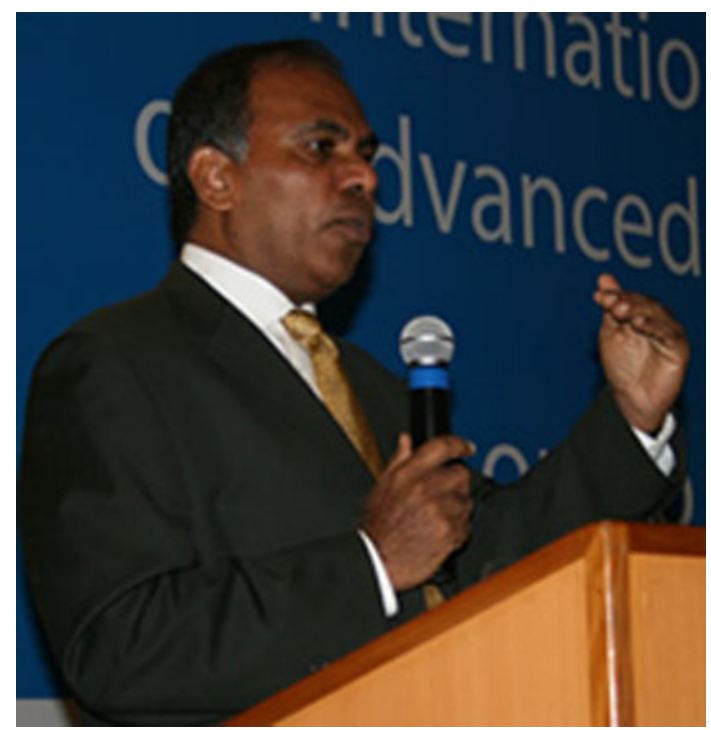

Fig. 1 Subra Suresh (MIT presenting his Plenary Talk) (Courtesy Gopal Rao, MRS)

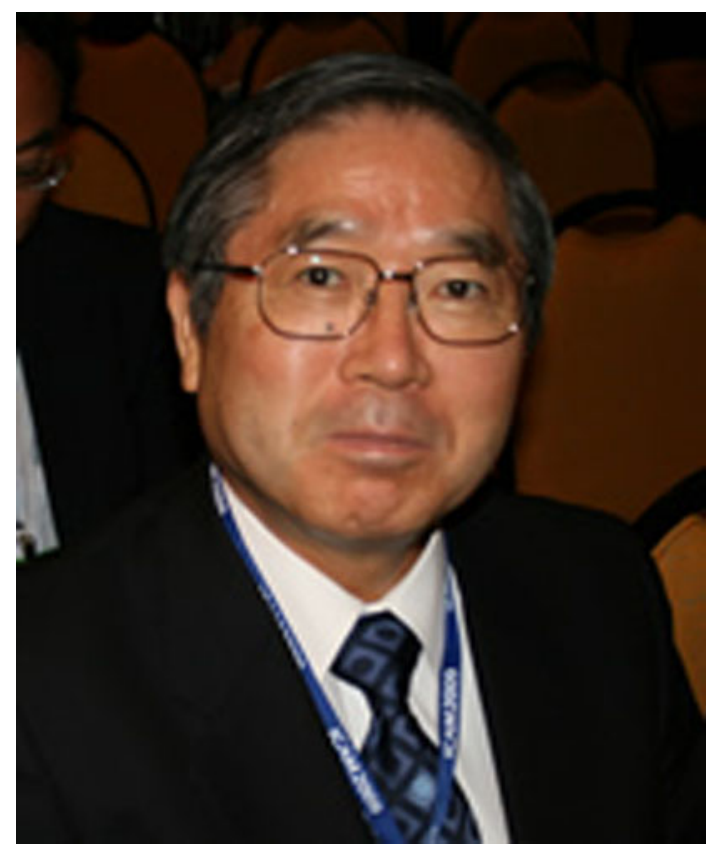

Fig. 2 Akihisa Inoue (Plenary Speaker) (Courtesy Gopal Rao, MRS)

The Meeting opened with an official ceremony which included welcome address talks delivered by the President of the Brazilian MRS, the Program Committee Chair, the Conference Chairman and Brazilian governmental authorities. The State Minister for Science and Technology, Sergio Rezende, delivered the opening lecture. All the oral presentations were delivered in English, which emphasized the international flavor of the meeting. A poster session was held each evening, and there was also an equipment exhibit. More than 1700 technical presentations were made ( 421 orally and 
Fig. 3 (left to right) Program chair Elisa Baggio Saitovitch, conference chair Guillermo Solórzano, Abdelilah Slaoui (European-MRS), Brazilian Minister for Science and Technology Sergio Rezende, Robert Chang (IUMRS), Shefford Baker (MRS), Brazilian-MRS (SBPMat) President Fernando Lázaro Freire Jr., and Sandoval Carneiro Jr. (CAPES, Brazil) (Courtesy Gopal Rao, MRS)

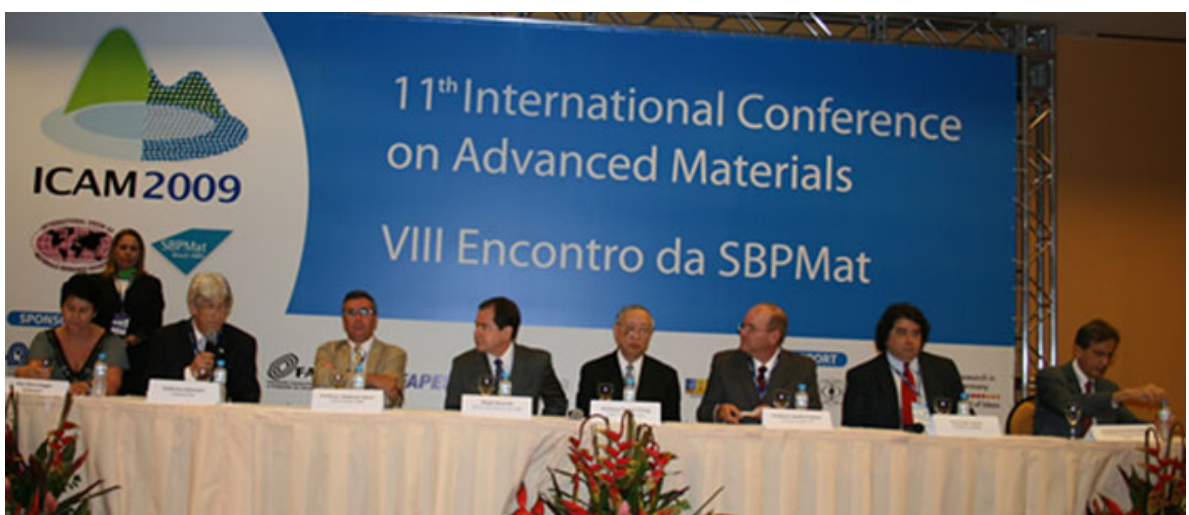

1343 posters) and the strongly interdisciplinary program provoked lively discussions both informally and in the formal sessions. The conference also featured two workshops: "Innovation in Materials Research" and "Global Nanotechnology Network", and a Energy Forum (Fig. 3).

With a population of around 6 million, the city of Rio de Janeiro ranks 2nd in Brazil and is the second major metropolitan area in the southern region of the country. Surrounded by beautiful beaches and mountain scenery, Rio de Janeiro is an exuberant and cosmopolitan city with very pleasant weather in September. Easy access from all over the world, allowed participation of delegates from all the IUMRS affiliate societies to come to friendly Rio and feel at home.

Rio is not only a beautiful city but also a vibrant scientific, intellectual and cultural center in Brazil. ICAM 2009 in Rio was the event for an update on the challenges at the frontiers of Material Science and related technologies. Previous Brazilian MRS meting took place in Rio de
Janeiro (2002 and 2003), Foz de Iguaçu (2004), in Recife (2005), in Florianopolis (2006), in Natal (2007), and in Guaruja (2008), sites also famous for their natural beauty and hospitality.

The papers contained in this special issue are from topics presented in different symposia; therefore, this volume does not capture the full spectrum of activities that were discussed. We hope, however, that it provides a sense of the rich variety of activities involved in the meeting, thus displaying the interdisciplinary nature of the society.

I would like to thank all participants for contributing to the success of the 11th ICAM and the 8th Brazilian MRS Meeting. We wish to extend our appreciation to those who reviewed manuscripts for its volume. We would also like to express our gratitude to the following Brazilian funding agencies and institutions for the financial support: $\mathrm{CNPq}$, CAPES, FAPERJ, FAPESP, FINEP, MCT, PETROBRAS, PUC-Rio, and CBPF. 